The Free Internet Journal

for Organic Chemistry
Paper

Arkivoc 2019, part iv, 0-0

to be inserted by editorial office

\title{
A gram-scale synthesis of a macrocyclic amidinourea with strong antifungal activity through a Fukuyama tri-protected polyamine intermediate
}

\author{
Matteo Borgini, ${ }^{a}$ Francesco Orofino, ${ }^{a}$ Giuseppina I. Truglio, ${ }^{a}$ Lorenzo Balestri, ${ }^{a}$ and Maurizio Botta*a,b,c \\ a Department of Biotechnology, Chemistry and Pharmacy, University of Siena, I-53100 Siena, Italy \\ b Sbarro Institute for Cancer Research and Molecular Medicine, Centerfor Biotechnology, College of Science \\ and Technology, Temple University, Philadelphia, PA, United States of America. \\ c Lead Discovery Siena s.r.l, Via Vittorio Alfieri 31, I-53019 Castelnuovo Berardenga, Italy \\ Email: botta.maurizio@gmail.com
}

Dedicated to Steve, thanking him for his great ability to teach and his dedication

Received 01-30-2019

Accepted 05-04-2019

Published on line 05-16-2019

\section{Abstract}

Systemic fungal infections are, nowadays, of crucial importance and, thus, in the last decade, we explored the great potential of natural and synthetic guanylated compounds, a great amount of work that led to the development of new non-azole antifungal compounds bearing a macrocycle, endowed with potent antifungal activity. We planned many biological assays to evaluate this class, implying always greater amount of compounds needed. This triggered us to setup a convenient strategy to prepare, in an easy and affordable way, grams of compound to be tested in excellent overall yield.

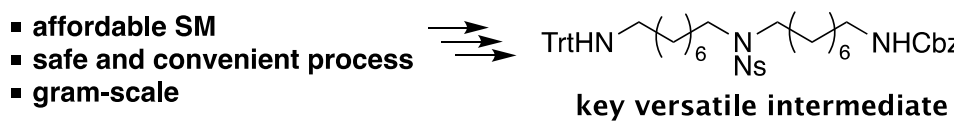

key versatile intermediate
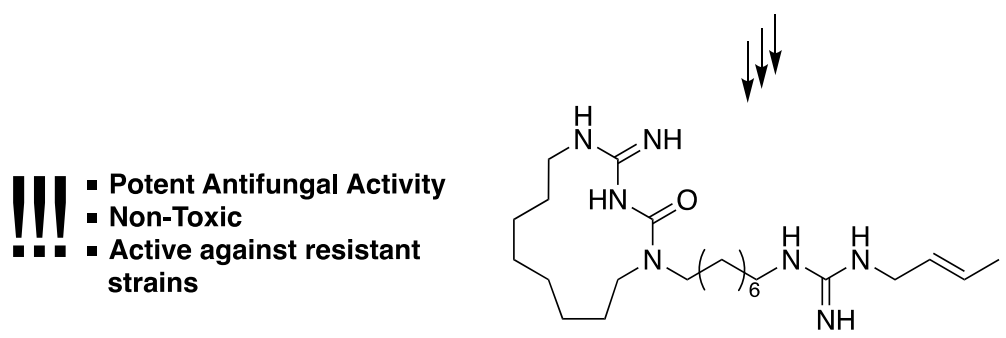

Keywords: Macrocyclic compounds, antifungals, polyamines, amidinoureas 


\section{Introduction}

The development of an effective synthetic method for amines and polyamines has always been a key interest in organic chemistry, biochemistry and medicinal chemistry, because of the synthetic challenges these compounds present and of the collection of interesting biological activities they possess, such as their involvement in cancer or virus infections. ${ }^{1-3}$ The presence of dedicated polyamine transporters into cell membranes as well as dedicated enzymatic machineries for their synthesis and metabolism stress their importance in cell's and organism's life cycles. ${ }^{4-7}$

The highly polar nature of these compounds makes their handling difficult, time-consuming and sometimes expensive. Moreover, the selection of the proper protective groups for the nitrogen atoms is usually a pivotal moment in synthesis planning, above all if natural macromolecules preparation is involved. Hence, many scientists devoted part of their work to the analysis of protecting group strategies, as testified by the remarkable work done in late 1990 s/early 2000 s by Fukuyama and co-workers, ${ }^{8-12}$ as well as by many others. ${ }^{13-23}$

In the last years, our research group focused its efforts on the preparation of a series of compounds bearing interesting antifungal properties, as we reported in previous works, ${ }^{24-32}$ well represented by compound 1 (Figure 1). These compounds showed good activities against various Candida strains, most notably albicans, guillermondii, kefyr, glabrata. Their main point of strength, though, is their ability to improve the antifungal activity against strains presenting resistance to azoles, the most widely used antifungal drugs at the moment, as well as a good ADMET profile. ${ }^{32}$ Being these the most desirable characteristics novel antifungals should have, we decided to investigate them even further, so we faced the need to prepare amounts of compound 1 higher than what we usually managed. In the first described synthesis of 1,27 the commercially available bis(8-aminooctyl)amine was used. Two subsequent guanylations of the primary amino groups, by using $N, N^{\prime}-$ di-Boc-S-methylisothiourea and $N, N^{\prime}$-di-Boc- $N$-[(E)-but-2-en]-S-methylisothiourea respectively, followed by a cyclization in refluxing THF in presence of TEA and a final Boc deprotection, led to the desired compound. However, since bis(8-aminooctyl)amine was no longer commercially available (with the exception of custom synthesis services), new synthetic paths had to be taken. Here follows a detailed analysis of these paths, with their obstacles and downsides, that finally led us to setup a convenient and versatile way to prepare our lead compound 1 in gram scale.

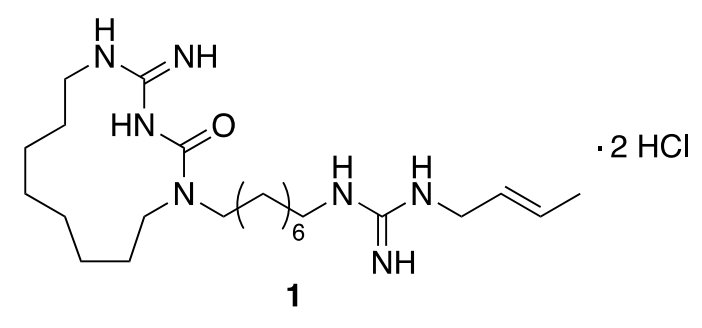

Figure 1: Structure of compound 1. 


\section{Results and Discussion}

Since the withdrawal from the market of the bis(8-aminooctyl)amine, two different solutions were explored (Figure 2). The first option was the synthesis of bis(8-aminooctyl)amine itself in four steps starting from 1,8dibromooctane. ${ }^{33}$ In a second approach, the macrocyclic scaffold was obtained by reducing with DIBAL-H the amide obtained by coupling the mono-guanilated-1,8-diaminoctane and the Cbz-protected 8-aminooctanoic acid. ${ }^{25}$

Both the described approaches, though, are not suitable for obtaining grams of 1 . The first approach, besides using the unsafe sodium azide, implies a quite heavy workload to obtain the bis(8-aminooctyl)amine. This is mainly ascribed to the purification of the 1-azido-8-bromooctane, which implies long isocratic hexane chromatography given the high similarity in terms of polarity the product and the starting material present. The difficulties that are faced in case one of the free amines needs to be purified is another aspect that involves overload of work. Besides, it is then used in a 3:1 ratio for the selective mono-alkylation, leading to a waste of unrecoverable starting material (alongside the wasting of time and expensive work). The second approach gets over this problem by anticipating the mono-guanylation in the synthetic process. DIBAL-H, though, is the only reducing agent that can be used for the amide reduction due to the presence of other carbonyl groups, which led to moderate to low yields, difficult purifications (including work-up with Rochelle salt leading to a viscous mass which is hard to handle), lack of a good reproducibility (since DIBAL-H quality tends to decay over time) and still not suitable for a scaling-up procedure. Over time, other alternatives were explored, but they failed to solve the abovementioned problems. ${ }^{34}$

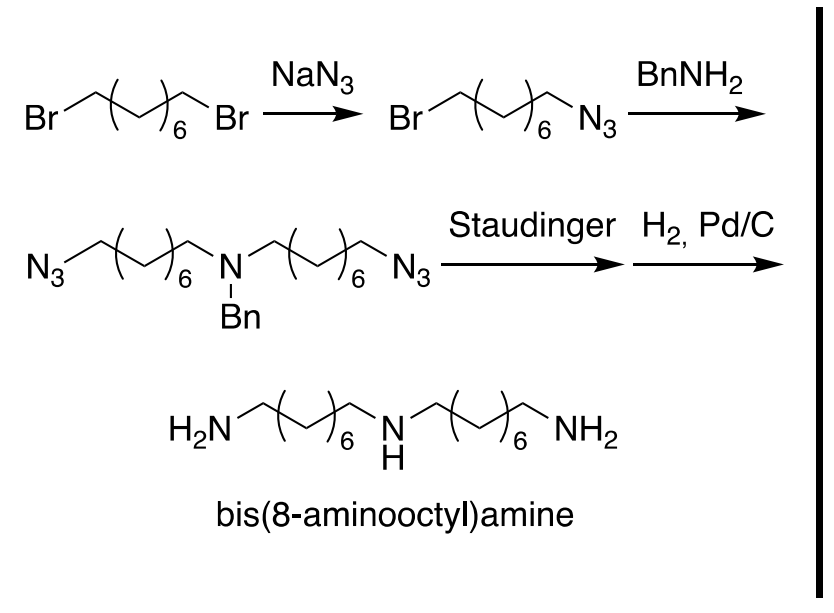

- Uses hazardous $\mathrm{NaN}_{3}$

- Heavy Workloads

- 3:1 ratio -> waste of product

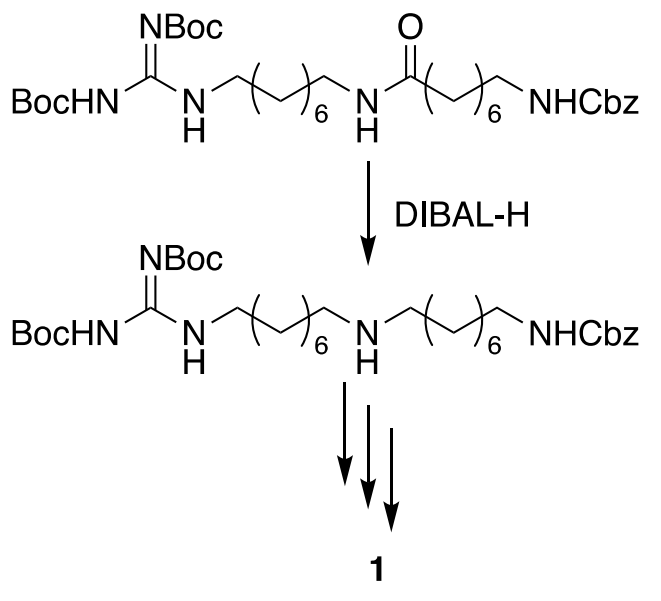

- Moderate to low yield

- Difficult purification

- Lack of reproducibility

Figure 2: Summary of the synthetic strategies explored.

To overcome the described limitations, we took inspiration from Fukuyama's work designing a novel synthetic strategy. This allowed us to prepare grams of $\mathbf{1}$ in a single batch, in the same timeframe of the old approaches. The keystone is to obtain intermediate bis(8-aminooctyl)amine in the tri-protected form 6, with trityl, Cbz and nosyl as protecting groups of choice. This intermediate offers many advantages, such as lowering of both time and costs of production (because protecting groups make it less polar and easier to handle and purify) and 
versatility, since the three different groups are orthogonal to each other, meaning they can be selectively removed in different conditions, allowing us to deprotect only the chosen amine; this avoids resorting to workarounds like the use of 3:1 ratio and waste of materials by means of simple one-pot-two-steps reactions. We prepared the diamine 4 (Scheme 1) by mono-protecting the diaminooctane with trityl chloride and, subsequently, with nosyl chloride, at room temperature. The amino-alcohol $\mathbf{5}$ was obtained via a direct reduction of the carboxylic acid by using borane dimethylsulfide, in high yield. The tri-amine 6, then, was synthesized using Mitsunobu reaction conditions. The resulting product $\mathbf{6}$ was easily purified by flash chromatography allowing the recovery of the unreacted di-protected amine 4. Another economical advantage of this approach is that affordable diaminoctane is wasted during mono-protection in place of the more expensive bis(8-aminooctyl)amine. All the reaction steps occur with good yields and without difficulties.

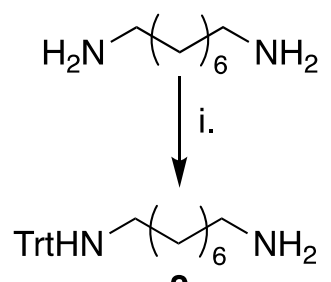

2

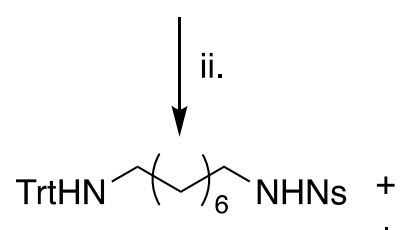

4

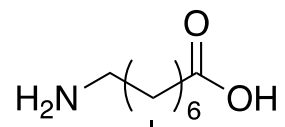

iii.

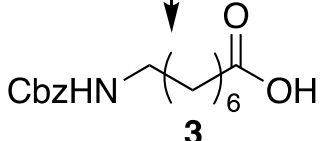

3

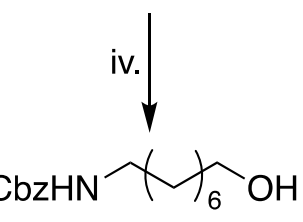

5

v.

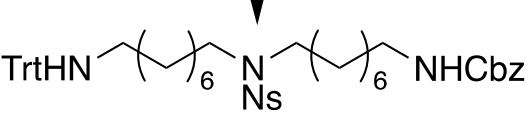

6

Scheme 1: Synthesis of intermediate 6. i. Trityl chloride, DCM, $0{ }^{\circ} \mathrm{C}$ to r. t., $2 \mathrm{~h}, 96 \%$; ii. Nosyl chloride, DIPEA, DCM, r. t., 1 h, $95 \%$; iii. $\mathrm{CbzCl}, \mathrm{NaHCO}_{3}, \mathrm{H}_{2} \mathrm{O} / \mathrm{THF},-10{ }^{\circ} \mathrm{C}$ to r. t., o. n., 87\%; iv. $\mathrm{Me}_{2} \mathrm{SBH}_{3}$, dry THF, r. t., o. n. $93 \%$; v. DIAD, PPh 3 , dry THF, r. t., 3 h, $76 \%$.

The three subsequent reactions have the advantage of being one-pot-two-steps. Specifically, the first one (the deprotection of trityl group and guanylation of the primary salified amine) was carried out with TFA and Et ${ }_{3} \mathrm{SiH}$ in DCM and subsequent treatment with $N, N^{\prime}$-Di-Boc- $1 H$-pyrazole-1-carboxamidine and DIPEA to afford compound 7. In the deprotection step, the excess of $\mathrm{Et}_{3} \mathrm{SiH}$ was removed in vacuo as the remaining TFA and DCM, leaving the salified amine and the inert triphenylmethane ready for the guanylation step. 7 is easily purified by flash chromatography given the lack of free amine groups, with an excellent overall yield of $99 \%$. The following reaction, the nosyl deprotection, was carried out using thiophenol and $\mathrm{K}_{2} \mathrm{CO}_{3}$ in dry DMF. The excess of thiophenol and $\mathrm{K}_{2} \mathrm{CO}_{3}$ were eliminated during the work-up after washing with water and $5 \% \mathrm{NaHCO}_{3}$, while the byproduct 1-nitro-4-(phenylsulfanyl)benzene is left in place, since it does not interfere with the next step. At this point, the solvent was removed and the crude product was heated at reflux with TEA in THF giving compound 8 ( $52 \%$ yield), again avoiding any possible problem during the purification of the intermediate. For this step, we exploited the tendency of di-Boc-protected guanidine to give amidinoureas when heated at reflux in THF in presence of an amine. ${ }^{35,36}$ This ability results from the conversion of one of the Boc protecting 
group of the guanidine into isocyanate through a $t$-butoxide elimination and subsequent nucleophilic attack by the amine. In our case, the reaction occurs through an intramolecular attack, which leads to the formation of a macrocycle.

For the last guanylation, the macrocyclic amidinourea 8 was $\mathrm{Cbz}$ deprotected using $\mathrm{H}_{2}$ over $10 \% \mathrm{Pd} / \mathrm{C}$ in presence of catalytic aqueous $\mathrm{HCl} 37 \%$, guanylated with 9 getting compound 10 (90\% yield). The latter guanylating agent was easily prepared from $N, N^{\prime}$-Di-Boc- $1 H$-pyrazole-1-carboxamidine and crotyl alcohol using Mitsunobu condition, adapting a previously described procedure. ${ }^{25,27}$

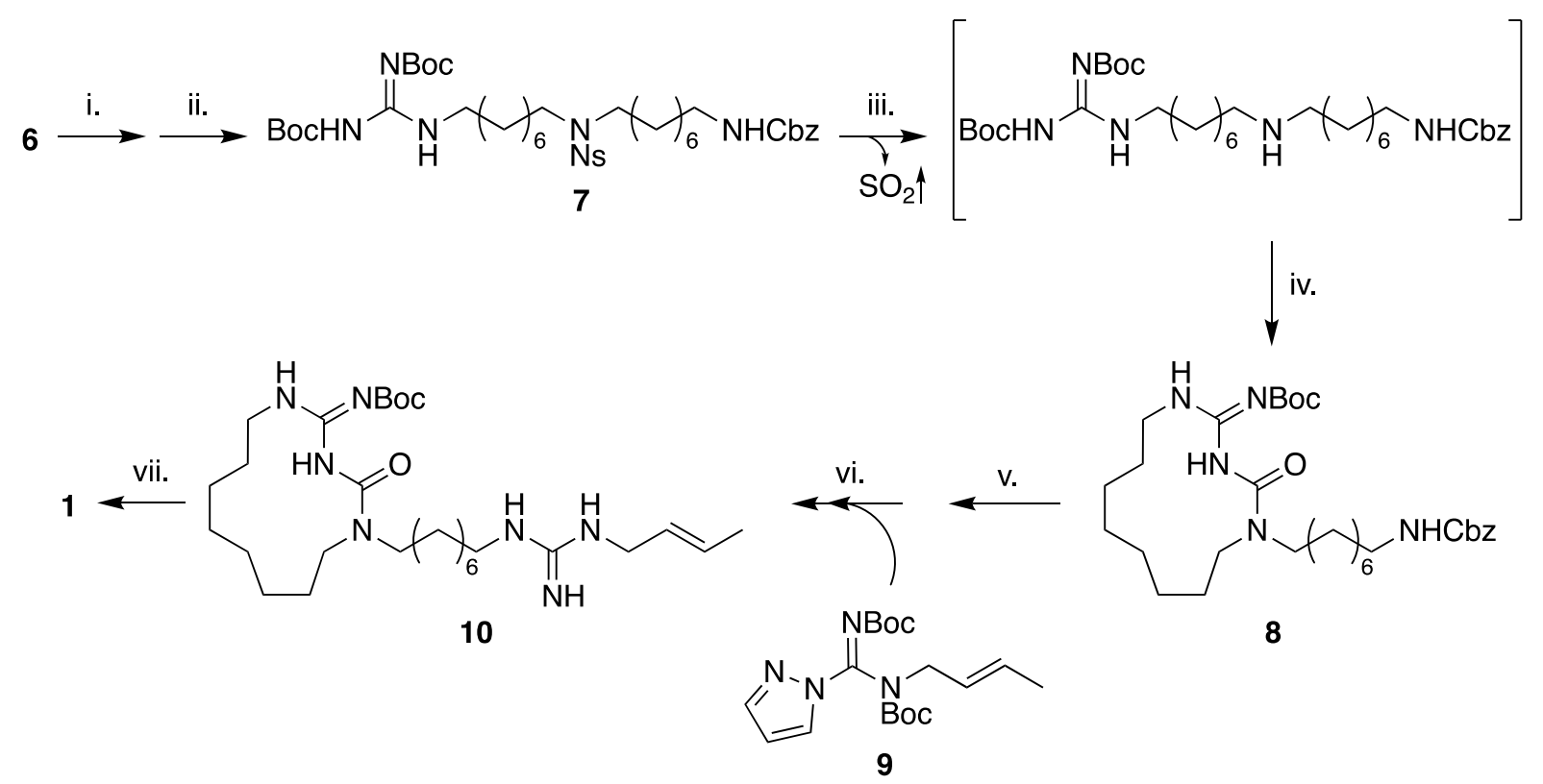

Scheme 2: Last steps of the synthesis of compound 1. i. TFA, Et ${ }_{3} \mathrm{SiH}, \mathrm{DCM}, 0^{\circ} \mathrm{C}$ to r. t., $1 \mathrm{~h} ; \mathrm{ii} . \mathrm{N}, \mathrm{N}^{\prime}-\mathrm{Di}-\mathrm{Boc}-1 \mathrm{H}-$ pyrazole-1-carboxamidine, DIPEA, THF, r. t., $16 \mathrm{~h}, 96 \%$ over two steps; iii. Thiophenol, $\mathrm{K}_{2} \mathrm{CO}_{3}$, dry DMF, r. t., 7 h; iv. TEA, THF, reflux, 16 h, 57\% over two steps; v. $\mathrm{H}_{2}, 10 \% \mathrm{Pd} / \mathrm{C}$, cat. $37 \% \mathrm{HCl}, i-\mathrm{PrOH}, \mathrm{r}$. t., 3 h; vi. 9, TEA, THF, r. t., $16 \mathrm{~h}, 89 \%$ over two steps; vii. $\mathrm{HCl} 4 \mathrm{M}$ in Dioxane, $23 \mathrm{~h}$, quantitative.

\section{Conclusions}

The synthesis of compound $\mathbf{1}$ always presented drawbacks, ranging from a very low overall yield, challenging purifications and handling of highly polar compounds, wasting of starting materials due to low molar ratios, and use of hazardous chemicals. During the long time we have worked on these molecules, we always managed to prepare the lab-scale quantity required for the early development without too much hassle, but the more advanced steps of drug discovery and development required higher amount of compounds which were really hard to prepare following the old habits, despite the familiarity we had with them. Spending time and efforts in the setup of an alternative synthetic strategy appeared, then, a good investment for the future of the project. And indeed it was, since a gram-scale synthesis of $\mathbf{1}$ was successfully performed, following a convenient, versatile and efficient route, with a great overall yield, a low cost and adequate amount of time, despite the process still involved the use and preparation of polyamines.

Compound 1 obtained via this process proved to possess the same physico-chemical properties and pharmacological activities of our previous batches, making this synthetic method a viable and valuable route 
to overcome all the limitations and difficulties our previous strategies implied, easing the challenging purpose of finding always novel and more active antifungal compounds. To this aim, the synthesis goes through the obtainment of the key intermediate 6 , whose synthetic flexibility could be very important in the planning of new derivatives. This process allowed us to perform advanced biological investigations on 1, e.g. in vivo assays, with very little requirements in terms of costs, manpower and time, pushing our understanding of its biological behavior even further, and allowing us to focus on the study of its mode of action.

\section{Experimental Section}

General. All reagents were used as purchased. $\mathrm{CHCl}_{3}, \mathrm{CH}_{3} \mathrm{CN}, \mathrm{DCM}, \mathrm{TEA}$ and DIPEA were dried by distillation from $\mathrm{CaH}_{2}$; THF from Na/Benzophenon. Chromatographic purifications were carried out with flash columns packaged with silica gel 60, 230-400 mesh and reactions were monitored using TLC purchased from Merck with silica gel $60 \mathrm{~F}_{254} .{ }^{1} \mathrm{H}-\mathrm{NMR}$ and ${ }^{13} \mathrm{C}-\mathrm{NMR}$ data were acquired on Bruker Avance DPX 400. As internal standard the residual signal of deuterated solvents was used and the chemical shift are reported in ppm. Splitting patterns are described as $\mathrm{s}=$ singlet, $\mathrm{d}=$ doublet, $\mathrm{t}=$ triplet, $\mathrm{q}=$ quartet, $\mathrm{m}=$ multiplet, $\mathrm{dq}=\mathrm{doublet}$ of quartet, bs = broad signal. Mass spectra data were obtained using Agilent 1100 LC/MSD VL system (G1946C).

(8-aminooctyl)(triphenylmethyl)amine (2) To an ice-cold solution of 1,8-Diaminoctane (14.5 g, $100.4 \mathrm{mmol}$ ) in DCM $(85 \mathrm{~mL})$, trityl chloride $(8 \mathrm{~g}, 28.7 \mathrm{mmol})$ was added portionwise. The resulting solution was stirred at room temperature for $2 \mathrm{~h}$. Then, the reaction mixture was partitioned between DCM/5\% $\mathrm{NaHCO}_{3} \mathrm{aq}_{\text {; }}$ the organic phase was washed with brine, dried over $\mathrm{Na}_{2} \mathrm{SO}_{4}$, filtered and evaporated in vacuo. The crude mixture was purified by chromatography on silica gel (DCM/MeOH 8:2) yielding compound 2 (10.6 g, 96\% yield, using trityl chloride as reference) as a yellow oil. $\mathrm{R}_{\mathrm{f}}=0.30$ (DCM/MeOH 9:1). $\left.{ }^{1} \mathrm{H} \mathrm{NMR} \mathrm{(400} \mathrm{MHz} \mathrm{CDCl}_{3}\right): \delta 7.47(\mathrm{~d}, J$ $6.8 \mathrm{~Hz}, 6 \mathrm{H}), 7.26(\mathrm{t}, J 7.9 \mathrm{~Hz}, 6 \mathrm{H}), 7.17(\mathrm{t}, J 7.0 \mathrm{~Hz}, 3 \mathrm{H}), 2.74(\mathrm{t}, J 6.6 \mathrm{~Hz}, 2 \mathrm{H}), 2.11(\mathrm{t}, J 8.0 \mathrm{~Hz}, 2 \mathrm{H}), 1.47(\mathrm{~m}, 3 \mathrm{H})$, $1.27(\mathrm{~m}, 7 \mathrm{H}), 0.88(\mathrm{~m}, 2 \mathrm{H}) .{ }^{13} \mathrm{C} \mathrm{NMR}\left(100 \mathrm{MHz} \mathrm{CDCl}_{3}\right): \delta 146.4,128.7,127.6,126.2,70.9,43.6,41.7,30.4,30.1$, 29.3, 27.8, 27.5, 27.3. LC-MS(ES) $m / z: 386.9[\mathrm{M}+\mathrm{H}]^{+}$.

4-nitro- $\boldsymbol{N}$-(8-(tritylamino)octyl)benzenesulfonamide (4) To $\quad$ a solution of (8aminooctyl)(triphenylmethyl)amine $(9.85 \mathrm{~g}, 25.49 \mathrm{mmol}$ ) and DIPEA (11.1 mL, $63.73 \mathrm{mmol})$ in DCM (150 mL), nosyl chloride $(5.65 \mathrm{~g}, 25.49 \mathrm{mmol})$ was added portionwise. The reaction mixture was stirred at room temperature for $1 \mathrm{~h}$. The mixture was diluted with DCM and extracted with water. The organic layer was washed with brine, dried over $\mathrm{Na}_{2} \mathrm{SO}_{4}$, filtered and evaporated. The crude mixture was purified by chromatography on silica gel (PE/AcOEt 7:3) yielding compound 4 (13.8 g, 95\% yield) as a pale yellow solid. $R_{f}=$ 0.42 (PE/AcOEt 8:2). ${ }^{1} \mathrm{H}$ NMR (400 MHz CDCl $): \delta 8.35$ (d, J $\left.8.2 \mathrm{~Hz}, 2 \mathrm{H}\right), 8.05$ (d, J $\left.8.4 \mathrm{~Hz}, 2 \mathrm{H}\right), 7.47$ (d, J $8.4 \mathrm{~Hz}$, $6 \mathrm{H}), 7.27$ (t, J $7.4 \mathrm{~Hz}, 6 \mathrm{H}), 7.19(\mathrm{~m}, 3 \mathrm{H}), 4.63$ (bs, $1 \mathrm{H}), 3.00$ (q, J 7.2Hz, 2H), $2.13(\mathrm{~m}, 2 \mathrm{H}), 1.58(\mathrm{~m}, 2 \mathrm{H}), 1.45(\mathrm{~m}$, $3 \mathrm{H}), 1.21(\mathrm{~m}, 7 \mathrm{H}) .{ }^{13} \mathrm{C}$ NMR $\left(100 \mathrm{MHz} \mathrm{CDCl}_{3}\right): \delta 150.0,146.2,128.7,128.3,128.2,127.8,126.3,124.4,48.3$, 43.7, 43.4, 29.6, 29.3, 28.9, 27.2, 26.7, 26.4. LC-MS(ES) $\mathrm{m} / \mathrm{z}: 571.9[\mathrm{M}+\mathrm{H}]^{+}$.

Benzyl (8-hydroxyoctyl)carbamate (5). To a solution of 3 (13 g, $44.3 \mathrm{mmol}$ ) in dry THF (150 mL), $\mathrm{Me}_{2} \mathrm{SBH}_{3}(12.6$ $\mathrm{mL}, 132.9 \mathrm{mmol}$ ) was added dropwise. The reaction mixture was stirred overnight under $\mathrm{N}_{2}$ atmosphere. Once starting material disappeared (monitored by $\mathrm{TLC}$ ), $\mathrm{H}_{2} \mathrm{O}$ was added dropwise. Then, $\mathrm{K}_{2} \mathrm{CO}_{3}$ was added and the mixture was stirred for 30'. Subsequently, AcOEt was added and the organic layer was washed with $1 \mathrm{~N} \mathrm{NaOH}$ and brine, dried over $\mathrm{Na}_{2} \mathrm{SO}_{4}$, filtered and evaporated. The crude mixture was purified by flash chromatography on silica gel (PE/AcOEt 6:4) yielding compound 5 as a white solid (12.4 g, 93\% yield). $R_{f}=0.18$ (PE/AcOEt 6:4). ${ }^{1} \mathrm{H}$ NMR (400 MHz CDCl 3 ): $\delta 7.33(\mathrm{~m}, 5 \mathrm{H}), 5.09(\mathrm{~s}, 2 \mathrm{H}), 4.72(\mathrm{bs}, 1 \mathrm{H}), 3.63(\mathrm{t}, J 6.4 \mathrm{~Hz}, 2 \mathrm{H}), 3.18$ 
(q, J 6.4 Hz, 2H), 1.57-1.49 (m, 6H), 1.31 (m, 6H). ${ }^{13} \mathrm{C}$ NMR $\left(100 \mathrm{MHz} C D C l_{3}\right): \delta 156.8,136.9,128.7,128.2,128.0$, $66.7,62.9,41.3,32.9,30.1,29.5,29.4,26.9,25.9$. LC-MS(ES) $m / z: 279.9[\mathrm{M}+\mathrm{H}]^{+}$.

benzyl (8-((4-nitro- $\mathbf{N}$-(8-(tritylamino)octyl)phenyl)sulfonamido)octyl)carbamate (6). 4 (5 g, 8.74 mmol) was dissolved in dry THF (50 mL) and treated sequentially with $\mathrm{PPh}_{3}(2.12 \mathrm{~g}, 10.49 \mathrm{mmol}), 5$ (2.93 g, $\left.10.49 \mathrm{mmol}\right)$ and DIAD (2.7 mL, $10.49 \mathrm{mmol})$ and the reaction mixture was stirred for $3 \mathrm{~h}$, under $\mathrm{N}_{2}$, at room temperature. Then, the solvent was removed and the residue was partitioned between $\mathrm{H}_{2} \mathrm{O} / D C M$, washed with brine, dried over $\mathrm{Na}_{2} \mathrm{SO}_{4}$, filtered and evaporated in vacuo. The crude was purified by column chromatography on silica gel (PE/AcOEt 9:1 to 8:2) giving compound 6 as a colourless oil (5.54 g, 76\% yield). $R_{f}=0.26$ (PE/AcOEt 8:2). ${ }^{1} \mathrm{H}$ NMR (400 MHz CDCl $): \delta 8.33(\mathrm{~d}, J 8.6 \mathrm{~Hz}, 2 \mathrm{H}), 7.96(\mathrm{~d}, J 8.0 \mathrm{~Hz}, 2 \mathrm{H}), 7.47(\mathrm{~d}, J 7.4 \mathrm{~Hz}, 7 \mathrm{H}), 7.26(\mathrm{~m}, 10 \mathrm{H}), 7.18$ $(\mathrm{t}, J 7.6 \mathrm{~Hz}, 3 \mathrm{H}), 5.09(\mathrm{~s}, 2 \mathrm{H}), 4.72(\mathrm{bs}, 1 \mathrm{H}), 3.15(\mathrm{~m}, 6 \mathrm{H}), 2.11(\mathrm{t}, J 7.0 \mathrm{~Hz}, 2 \mathrm{H}), 1.57(\mathrm{~m}, 4 \mathrm{H}), 1.49(\mathrm{~m}, 6 \mathrm{H}), 1.26$ $(\mathrm{m}, 14 \mathrm{H}) .{ }^{13} \mathrm{C}$ NMR $\left(100 \mathrm{MHz} \mathrm{CDCl}_{3}\right): \delta 156.2,150.0,146.3,136.2,129.1,128.9,128.7,128.3,127.6,127.5$, 127.1, 126.9, 67.4, 50.2, 45.3, 40.1, 29.6, 29.4, 29.1, 28.5, 28.3, 27.9, 27.6, 27.4, 26.9, 26.8, 26.6, 26.3. LCMS(ES) $m / z: 833.8[\mathrm{M}+\mathrm{H}]^{+}$.

\section{benzyl}

$\mathbf{N}$-[8-(N-\{8-[(\{[(tert-butoxy)carbonyl]amino\}(\{[(tert-butoxy)carbonyl]imino\})methyl)amino]octyl\}4-nitrobenz enesulfonamido)octyl]carbamate (7). To a solution of $6(3.5 \mathrm{~g}, 4.20 \mathrm{mmol})$ in $\mathrm{DCM}(38 \mathrm{~mL})$, cooled at $0{ }^{\circ} \mathrm{C}$, $\mathrm{Et}_{3} \mathrm{SiH}(2.02 \mathrm{~mL}, 12.60 \mathrm{mmol})$ and TFA $(1.9 \mathrm{~mL}, 5 \%)$ were added. The reaction mixture was allowed to reach room temperature and stirred under $\mathrm{N}_{2}$ for $1 \mathrm{~h}$. After that time, the mixture was concentrated in vacuo and co-evaporated several times with DCM until a white solid formed. The crude mixture was dissolved in dry THF $(70 \mathrm{~mL})$ and to this solution, dry DIPEA $(1.1 \mathrm{~mL}, 6.30 \mathrm{mmol})$ was added dropwise at room temperature. Then, $N, N^{\prime}$-Di-Boc- $1 H$-pyrazole-1-carboxamidine $(1.70 \mathrm{~g}, 5.46 \mathrm{mmol})$ was added in one pot. The reaction mixture was stirred at room temperature for $16 \mathrm{~h}$, under nitrogen atmosphere. The mixture was partitioned between $\mathrm{H}_{2} \mathrm{O} / \mathrm{AcOEt}$, the organic layer was washed with brine, dried over $\mathrm{Na}_{2} \mathrm{SO}_{4}$ and evaporated to dryness. Purification by silica gel chromatography (PE/AcOEt 8:2) afforded compound 7 as a viscous oil (3.36 g, $96 \%$ yield over two steps). $R_{f}=0.11$ (PE/AcOEt 9:1). $\left.{ }^{1} \mathrm{H} \mathrm{NMR} \mathrm{(400} \mathrm{MHz} \mathrm{CDCl} 3\right): \delta 11.50(\mathrm{~s}, 1 \mathrm{H}), 8.35(\mathrm{~d}, J 8.2 \mathrm{~Hz}, 2 \mathrm{H})$, $7.98(\mathrm{~d}, J 8.8 \mathrm{~Hz}, 2 \mathrm{H}), 7.35(\mathrm{~m}, 5 \mathrm{H}), 5.10(\mathrm{~s}, 2 \mathrm{H}), 4.76(\mathrm{bs}, 1 \mathrm{H}), 3.41(\mathrm{q}, J 5.8 \mathrm{~Hz}, 2 \mathrm{H}), 3.15(\mathrm{~m}, 6 \mathrm{H}), 1.50(\mathrm{~m}, 28 \mathrm{H})$, $1.27(\mathrm{~m}, 14 \mathrm{H}) .{ }^{13} \mathrm{C} \mathrm{NMR}\left(100 \mathrm{MHz} \mathrm{CDCl}_{3}\right): \delta 166.1,157.1,154.1,150.1,146.2,136.4,129.1,128.7,128.3,127.2$, 124.5, 82.1, 48.2, 43.7, 29.7, 29.2, 28.5, 28.4, 27.8, 27.4, 26.9, 26.7, 26.5, 26.3. LC-MS(ES) m/z: $834.0[\mathrm{M}+\mathrm{H}]^{+}$. benzyl (8-(4-((tert-butoxycarbonyl)imino)-2-oxo-1,3,5-triazacyclotridecan-1-yl)octyl)carbamate (8). To a stirred solution of 7 (3.30 g, $3.96 \mathrm{mmol})$ in dry DMF $(17 \mathrm{~mL}), \mathrm{K}_{2} \mathrm{CO}_{3}(2.19 \mathrm{~g}, 15.84 \mathrm{mmol})$ and Thiophenol (0.8 $\mathrm{mL}, 7.92 \mathrm{mmol}$ ) were added and the reaction mixture was stirred at room temperature for $7 \mathrm{~h}$. The reaction mixture was partitioned between $\mathrm{H}_{2} \mathrm{O} / \mathrm{AcOEt}$, the water layer was extracted with AcOEt twice and the organic layers were washed with brine, dried over $\mathrm{Na}_{2} \mathrm{SO}_{4}$, filtered and evaporated in vacuo. The crude mixture was solubilized in dry THF $(600 \mathrm{~mL})$ and to this, dry TEA $(0.55 \mathrm{~mL}, 3.96 \mathrm{mmol})$ was added. The resulting solution was heated at reflux for $16 \mathrm{~h}$, under $\mathrm{N}_{2}$. The solvent was evaporated and the crude purified by flash chromatography (PE/AcOEt 85:15), affording compound 8 (1.3 g, 57\% yield over two steps) as a colorless oil. $\mathrm{R}_{\mathrm{f}}$ $=0.56$ (PE/AcOEt 8:2). ${ }^{1} \mathrm{H}$ NMR (400 MHz CDCl 3 ): $\delta 12.10(\mathrm{~s}, 1 \mathrm{H}), 8.10$ (bs, 2H), $7.35(\mathrm{~m}, 5 \mathrm{H}), 5.09(\mathrm{~s}, 2 \mathrm{H}), 4.71$ (bs, $1 \mathrm{H}), 3.45(\mathrm{~m}, 2 \mathrm{H}), 3.38(\mathrm{q}, \mathrm{J} 7.54 \mathrm{~Hz}, 2 \mathrm{H}), 3.26-3.15(\mathrm{~m}, 4 \mathrm{H}), 1.65(\mathrm{~m}, 6 \mathrm{H}), 1.54(\mathrm{~m}, 6 \mathrm{H}), 1.46(\mathrm{~m}, 12 \mathrm{H}), 1.27$

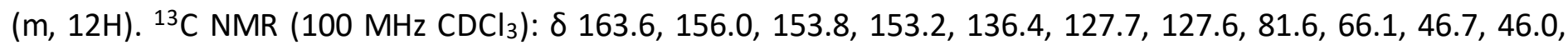
40.7, 39.3, 29.5, 29.1, 28.9, 28.1, 27.5, 26.7, 26.3, 25.9, 25.5, 24.9, 23.4 ppm. LC-MS(ES) m/z: $574.0[\mathrm{M}+\mathrm{H}]^{+}$, $595.9[\mathrm{M}+\mathrm{Na}]^{+}$.

tert-butyl ((E)-but-2-en-1-yl)((Z)-((tert-butoxycarbonyl)imino)(1H-pyrazol-1-yl)methyl)carbamate (9). To a stirred solution of $N, N^{\prime}$-di-Boc-pyrazologuanidine $(1,0 \mathrm{~g}, 3,22 \mathrm{mmol})$ in dry THF $(20 \mathrm{~mL})$ under $\mathrm{N}_{2}$ atmosphere, $\mathrm{PPh}_{3}(1,27 \mathrm{~g}, 4,19 \mathrm{mmol})$ and crotyl alcohol $(0,36 \mathrm{~mL}, 4,19 \mathrm{mmol})$ were added. The mixture was cooled to $0{ }^{\circ} \mathrm{C}$ 
and $\operatorname{DIAD}(0,91 \mathrm{~mL}, 4,84 \mathrm{mmol})$ was added dropwise. The mixture was stirred at $0{ }^{\circ} \mathrm{C}$ for $15 \mathrm{~min}$ then at room temperature for $2 \mathrm{~h}$, then it was diluted with AcOEt and washed with water. The aqueous phase was backextracted with AcOEt. The combined organic phases were washed with brine, dried over $\mathrm{Na}_{2} \mathrm{SO}_{4}$, filtered and evaporated under reduced pressure. The crude residue was purified with flash chromatography on silica gel, eluting with $10 \%$ AcOEt/Hex to give pure compound 9 (0.95 g, 95\% yield). ${ }^{1} \mathrm{H}$ NMR (400 $\left.\mathrm{MHz}^{\mathrm{CDCl}} 3\right) \delta 7.89(\mathrm{~s}$, 1H), $7.66(\mathrm{~s}, 1 \mathrm{H}), 6.37(\mathrm{~s}, 1 \mathrm{H}), 5.60(\mathrm{~m}, 2 \mathrm{H}), 4.18(\mathrm{~m}, 2 \mathrm{H}), 1.62(\mathrm{~s}, 3 \mathrm{H}), 1.44(\mathrm{~s}, 9 \mathrm{H}), 1.22(\mathrm{~s}, 9 \mathrm{H}) . \mathrm{LC}-\mathrm{MS}(\mathrm{ES}) \mathrm{m} / \mathrm{z}=$ $387.1[\mathrm{M}+\mathrm{Na}]^{+}, 365.1[\mathrm{M}+\mathrm{H}]^{+}$.

tert-butyl (5-(8-(3-((E)-but-2-en-1-yl)guanidino)octyl)-4-oxo-1,3,5-triazacyclotridecan-2-ylide $n$ e) ca r b a $\mathrm{m}$ at e (10). To a solution of 8 (1.30 g, $2.26 \mathrm{mmol})$ in $i$-PrOH $(125 \mathrm{~mL}), \mathrm{Pd} / \mathrm{C} 10 \mathrm{wt} . \%$ (96 mg, $0.90 \mathrm{mmol})$ and $14 \mathrm{drops}$ of $37 \% \mathrm{HCl}$ were added. The reaction mixture was stirred for $48 \mathrm{~h}$ under $\mathrm{H}_{2}$ atmosphere. Once starting material disappeared (monitored by TLC), the reaction mixture was filtered through a pad of Celite using 85:15 DCM:MeOH as solvent. The filtrate was evaporated in vacuo to dryness and resolubilized in dry THF (38 $\mathrm{mL}$ ). To this solution, dry TEA $(0.47 \mathrm{~mL}, 3.40 \mathrm{mmol})$ was added dropwise and then, 9 (1.07 g, $2.94 \mathrm{mmol})$ was added in one pot. The reaction mixture was stirred at room temperature overnight, under $\mathrm{N}_{2}$. The reaction mixture was partitioned between $\mathrm{H}_{2} \mathrm{O} / \mathrm{AcOEt}$, washed with brine, dried over $\mathrm{Na}_{2} \mathrm{SO}_{4}$ and evaporated in vacuo. The crude mixture was purified by flash chromatography on silica gel (PE/AcOEt 85:15) yielding compound 10 (1.5 $\mathrm{g}$, 89\% yield over two steps) as a sticky colorless oil. $\mathrm{R}_{\mathrm{f}}=0.63$ (PE/AcOEt 8:2). ${ }^{1} \mathrm{H}$ NMR $\left(400 \mathrm{MHz} \mathrm{CDCl}_{3}\right): \delta 12.10$ $(\mathrm{s}, 1 \mathrm{H}), 8.08$ (bs, 1H), $5.65(\mathrm{dq}, J 15,6.2 \mathrm{~Hz}, 1 \mathrm{H}), 5.50(\mathrm{~m}, 1 \mathrm{H}), 4.17(\mathrm{~s}, 2 \mathrm{H}), 3.45(\mathrm{t}, J 8.0 \mathrm{~Hz}, 2 \mathrm{H}), 3.36(\mathrm{q}, J 7.0$ $\mathrm{Hz}, 2 \mathrm{H}), 3.24(\mathrm{~m}, 4 \mathrm{H}), 1.66(\mathrm{~m}, 7 \mathrm{H}), 1.56(\mathrm{~m}, 6 \mathrm{H}), 1.49(\mathrm{~s}, 11 \mathrm{H}), 1.46(\mathrm{~s}, 19 \mathrm{H}), 1.31(\mathrm{~m}, 13 \mathrm{H}) .{ }^{13} \mathrm{C} \mathrm{NMR}(100 \mathrm{MHz}$ $\left.\mathrm{CDCl}_{3}\right): \delta 164.0,154.1,153.6,82.0,47.1,46.3,39.6,29.4,29.2,28.5,28.2,28.1,27.9,27.1,26.8,26.2,25.9$, 25.3, 23.7, 23.6, 17.7. LC-MS(ES) $m / z: 736.1[\mathrm{M}+\mathrm{H}]^{+}$.

(E)-1-(but-2-en-1-yl)-3-(8-(4-imino-2-oxo-1,3,5-triazacyclotridecan-1-yl)octyl)guanidine (1). To 10 (1.5 g, 2.04 $\mathrm{mmol}), 4 \mathrm{~N} \mathrm{HCl}$ in Dioxane $(30 \mathrm{~mL})$ was added and the resulting solution was stirred for $23 \mathrm{~h}$ at room temperature. Then, the solvent was evaporated in vacuo and co-evaporated several times with DCM until a white solid was obtained (1.01 g, quantitative yield). MP: $96-99^{\circ} \mathrm{C} .{ }^{1} \mathrm{H}$ NMR (400 MHz MeOD): $\delta 5.75$ (dq, J 15.0, 8.0 Hz, 1H), $5.49(\mathrm{~m}, 1 \mathrm{H}), 3.75(\mathrm{~m}, 2 \mathrm{H}), 3.52(\mathrm{~m}, 2 \mathrm{H}), 3.41-3.34(\mathrm{~m}, 4 \mathrm{H}), 3.18(\mathrm{t}, J 8.0 \mathrm{~Hz}, 2 \mathrm{H}), 1.71(\mathrm{~m}, 7 \mathrm{H})$, $1.60(\mathrm{~m}, 4 \mathrm{H}), 1.38(\mathrm{~m}, 18 \mathrm{H}) .{ }^{13} \mathrm{C}$ NMR (100 MHz MeOD): $\delta$ 156.0, 155.4, 153.4, 128.7, 125.1, 46.9, 46.3, 42.7, $41.3,41.0,28.9,28.8,28.6,27.2,26.3,26.2,26.1,25.7,23.0,22.7,16.6$. LC-MS(ES) m/z: $436.3[\mathrm{M}+\mathrm{H}]^{+}$.

\section{Acknowledgements}

This work was partially funded by Cygnet Biosciences B.V., Kaya Richard J. Beaujon Z/N, Curaçao.

\section{References}

1. Minois, N.; Carmona-Gutierrez, D.; Madeo, F. Aging (Albany NY) 2011, 3, 716-732. http://dx.doi.org/10.18632/aging.100361

2. Mounce, B. C.; Olsen, M. E.; Vignuzzi, M.; Connor, J. H. Microbiol. Mol. Biol. Rev. 2017, 81, 517-12. http://dx.doi.org/10.1128/MMBR.00029-17

3. Casero, R. A.; Murray Stewart, T.; Pegg, A. E. Nature Reviews Cancer 2018, 18, 681-695. http://dx.doi.org/10.1038/s41568-018-0050-3

4. Pegg, A. E. IUBMB Life 2009, 61, 880-894. 
http://dx.doi.org/10.1002/iub.230

5. Pegg, A. E. J. Biol. Chem. 2016, 291, 14904-14912.

http://dx.doi.org/10.1074/ibc.R116.731661

6. Igarashi, K.; Kashiwagi, K. Biochem. J. 1999, 344 Pt 3, 633-642.

http://dx.doi.org/10.1042/bj3440633

7. Igarashi, K.; Kashiwagi, K. Int. J. Biochem. Cell Biol. 2019, 107, 104-115.

http://dx.doi.org/10.1016/j.biocel.2018.12.012

8. Fukuyama, T.; Jow, C.-K.; Cheung, M. Tet. Lett. 1995, 36, 6373-6374.

http://dx.doi.org/10.1016/0040-4039(95)01316-a

9. Fukuyama, T.; Cheung, M.; Jow, C.-K.; Hidai, Y.; Kan, T. Tetrahedron Letters 1997, 38, 5831-5834.

http://dx.doi.org/10.1016/s0040-4039(97)01334-8

10. Fukuyama, T.; Cheung, M.; Kan, T. Synlett 1999, 1999, 1301-1303.

http://dx.doi.org/10.1055/s-1999-2827

11. Hidai, Y.; Kan, T.; Fukuyama, T. Chem. Pharrm. Bull. 2000, 48, 1570-1576.

http://dx.doi.org/10.1248/cpb.48.1570

12. Kan, T.; Fukuyama, T. Chem. Commun. 2004, 353-7.

http://dx.doi.org/10.1039/b311203a

13. Nihei, K.-I.; Kato, M. J.; Yamane, T.; Konno, K. Tetrahedron 2006, 62, 8335-8350.

http://dx.doi.org/10.1016/j.tet. 2006.06.051

14. Golantsov, N. E.; Karchava, A. V.; Yurovskaya, M. A. Chemistry of Heterocyclic Compounds 2008, 44, 263294.

http://dx.doi.org/10.1007/s10593-008-0042-4

15. Ottesen, L. K.; Olsen, C. A.; Witt, M.; Jaroszewski, J. W.; Franzyk, H. Chem. Eur. J. 2009, 15, 2966-2978. http://dx.doi.org/10.1002/chem.200802044

16. Kobayashi, K.; Oishi, S.; Hayashi, R.; Tomita, K.; Kubo, T.; Tanahara, N.; Ohno, H.; Yoshikawa, Y.; Furuya, T.; Hoshino, M.; Fujii, N. J. Med. Chem. 2012, 55, 2746-2757.

http://dx.doi.org/10.1021/jm2016914

17. Miyahara, M.; Shiozaki, H.; Tukada, H.; Ishikawa, Y.; Oikawa, M. Tet. Lett. 2018, 59, 4259-4262. http://dx.doi.org/10.1016/j.tetlet.2018.10.045

18. Edwards, M. L.; Snyder, R. D.; Stemerick, D. M. J. Med. Chem. 1991, 34, 2414-2420. http://dx.doi.org/10.1021/jm00112a016

19. Andersen, T. F.; Strømgaard, K. Tet. Lett. 2004, 45, 7929-7933. http://dx.doi.org/10.1016/j.tetlet.2004.08.139

20. Panozzo-Zénere, E. A.; Porta, E. O. J.; Arrizabalaga, G.; Fargnoli, L.; Khan, S. I.; Tekwani, B. L.; Labadie, G. R. Eur. J. Med. Chem. 2018, 143, 866-880.

http://dx.doi.org/10.1016/j.ejmech.2017.11.069

21. Jagu, E.; Pomel, S.; Diez-Martinez, A.; Rascol, E.; Pethe, S.; Loiseau, P. M.; Labruère, R. Eur. J. Med. Chem. 2018, 150, 655-666.

http://dx.doi.org/10.1016/j.ejmech.2018.02.087

22. Carboni, B.; Vaultier, M.; Carrié, R. Tet. Lett. 1988, 29, 1279-1282.

http://dx.doi.org/10.1016/S0040-4039(00)80276-2

23. Edwards, M. L.; Stemerick, D. M.; McCarthy, J. R. Tetrahedron 1994, 50, 5579-5590.

http://dx.doi.org/10.1016/S0040-4020(01)85630-1 
24. Manetti, F.; Cona, A.; Angeli, L.; Mugnaini, C.; Raffi, F.; Capone, C.; Dreassi, E.; Zizzari, A. T.; Tisi, A.; Federico, R.; Botta, M. J. Med. Chem. 2009, 52, 4774-4785.

http://dx.doi.org/10.1021/jm900371z

25. Sanguinetti, M.; Sanfilippo, S.; Castagnolo, D.; Sanglard, D.; Posteraro, B.; Donzellini, G.; Botta, M. ACS Med. Chem. Lett. 2013, 4, 852-857.

http://dx.doi.org/10.1021/ml400187w

26. Dreassi, E.; Zizzari, A. T.; D'Arezzo, S.; Visca, P.; Botta, M. Journal of Pharmaceutical and Biomedical Analysis 2007, 43, 1499-1506.

http://dx.doi.org/10.1016/j.jpba.2006.10.029

27. Manetti, F.; Castagnolo, D.; Raffi, F.; Zizzari, A. T.; Rajamaki, S.; D'Arezzo, S.; Visca, P.; Cona, A.; Fracasso, M. E.; Doria, D.; Posteraro, B.; Sanguinetti, M.; Fadda, G.; Botta, M. J. Med. Chem. 2009, 52, 7376-7379. http://dx.doi.org/10.1021/jm900760k

28. Botta, M.; Raffi, F.; Visca, P. Linear and Cyclic Guanidine Derivatives, Method of Preparation and Uses Thereof 2009, WO2009113033.

29. Castagnolo, D.; Schenone, S.; Botta, M. Chem. Rev. 2011, 111, 5247-5300.

http://dx.doi.org/10.1021/cr100423x

30. Maccari, G.; Deodato, D.; Fiorucci, D.; Orofino, F.; Truglio, G. I.; Pasero, C.; Martini, R.; De Luca, F.; Docquier, J. D.; Botta, M. Bioorg. Med. Chem. Lett. 2017, 27, 3332-3336.

http://dx.doi.org/10.1016/j.bmcl.2017.06.016

31. Sanfilippo, S.; Posteraro, B.; Sanguinetti, M.; Botta, M.; Maccari, G.; De Luca, F.; Docquier, J. D.; Deodato, D. New Macrocyclic Amidinourea Derivatives, Methods of Preparation and Uses Thereof as Chitinase Inhibitors 2014, WO2014202697.

32. Deodato, D.; Maccari, G.; De Luca, F.; Sanfilippo, S.; Casian, A.; Martini, R.; D'Arezzo, S.; Bonchi, C.; Bugli, F.; Posteraro, B.; Vandeputte, P.; Sanglard, D.; Docquier, J. D.; Sanguinetti, M.; Visca, P.; Botta, M. J. Med. Chem. 2016, 59, 3854-3866.

http://dx.doi.org/10.1021/acs.jmedchem.6b00018

33. Pasero, C.; D'Agostino, I.; De Luca, F.; Zamperini, C.; Deodato, D.; Truglio, G. I.; Sannio, F.; Del Prete, R.; Ferraro, T.; Visaggio, D.; Mancini, A.; Guglielmi, M. B.; Visca, P.; Docquier, J. D.; Botta, M. J. Med. Chem. 2018, 61, 9162-9176.

http://dx.doi.org/10.1021/acs.jmedchem.8b00619

34. Zamperini, C.; Maccari, G.; Deodato, D.; Pasero, C.; D'Agostino, I.; Orofino, F.; De Luca, F.; Dreassi, E.; Docquier, J. D.; Botta, M. Sci. Rep. 2017, 7, 8251. http://dx.doi.org/10.1038/s41598-017-08749-6

35. Miel, H.; Rault, S. Tet. Lett. 1998, 39, 1565-1568. http://dx.doi.org/10.1016/S0040-4039(98)00025-2

36. Castagnolo, D.; Raffi, F.; Giorgi, G.; Botta, M. Eur. J. Org. Chem. 2009, 2009, 334-337. http://dx.doi.org/10.1002/ejoc.200801109 